\title{
Stowarzyszenie "Memorial" w Rosji a polityka historyczna państwa
}

DOI 10.35757/CIV.2016.18.17

Stowarzyszenie „Memoriał”, a dokładniej Międzynarodowe Stowarzyszenie Historyczno-Oświatowe, Dobroczynne i Obrony Praw Człowieka "Memoriał" - to jedna z najstarszych organizacji pozarządowych w Rosji, która swoją misję określa jako „działalność obywatelska, mająca na celu zrozumienie doświadczeń historycznych XX wieku i utrwalenie w świadomości społecznej oraz w praktyce działalności państwa wartości ludzkich, wolności, demokracji i prawa, a także pobudzenie w społeczeństwie aktywności obywatelskiej, skierowanej na realizację tych celów" ${ }^{1 "}$.

Celem niniejszego artykułu jest pokazanie, że misja „Memoriału” i zadania postawione sobie przez założycieli Stowarzyszenia na rzecz budowania pamięci historycznej sa nadal aktualne, ponieważ polityka historyczna państwa rosyjskiego nie zmienia się, gdyż władze, które ja prowadza, wyodrębniają $z$ historii kraju tylko fakty chwalebne, $z$ którymi społeczeństwo chętnie się utożsamia.

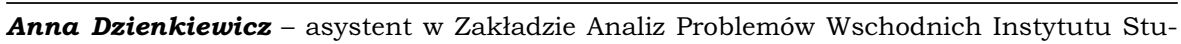
diów Politycznych PAN; wieloletnia szefowa programu dokumentacyjno-badawczego „Indeks Represjonowanych” w Ośrodku KARTA, redaktorka serii tomów „Indeksu”.

1 Zоb. "Мемориал" сегодня. Миссия и иели, <http://www.memo.ru/d/25.html> [dostęp: 1 września 2016 roku]. 
Należy podkreślić, że Międzynarodowe Stowarzyszenie „Memoriał" jest konfederacja pięćdziesięciu dwóch niezależnych organizacji, które działaja na terenie Rosji, Kazachstanu, Ukrainy, Łotwy, a także w Niemczech, we Włoszech i Francji. Najwyższym organem kierowniczym „Memoriału” jest Konferencja Sprawozdawczo-Wyborcza, zwoływana przez zarząd nie rzadziej niż raz na cztery lata. Jednocześnie odbywaja się konferencje sprawozdawczo-wyborcze Rosyjskiego Stowarzyszenia „Memoriał”, które ma oddziały w pięćdziesięciu regionach Federacji Rosyjskiej. Organizacje zrzeszone w międzynarodowym "Memoriale” sa samodzielne, maja równe prawa i obowiązi, określone w statucie. Maja też te same cele, ale zachowuja autonomię w wyborze priorytetów i działań. Niektóre $z$ nich skupiaja się przede wszystkim na prawnej i społecznej pomocy dawnym ofiarom, inne na upamiętnieniu ofiar, a jeszcze inne angażują się w obronę praw człowieka. Uchwały zarządu międzynarodowego „Memoriału” sa podejmowane wyłącznie w celu koordynowania prac i nie sa wiążące dla poszczególnych organizacji członkowskich. W Moskwie, w siedzibie zarządu międzynarodowego „Memoriału” działają dwa główne ośrodki - Ośrodek Badań, Informacji i Upowszechniania "Memoriał” oraz Ośrodek Obrony Praw Człowieka „Memoriał”, które inicjują różnego rodzaju projekty i organizują współpracę między regionalnymi „Memoriałami”2.

„Memoriał” od niemal trzydziestu lat realizuje swoje podstawowe cele: ujawnianie i zachowanie prawdy historycznej o zbrodniach totalitaryzmu i oporze wobec niego; upamiętnianie ofiar terroru państwowego; oddanie sprawiedliwości ofiarom masowych poważnych naruszeń praw człowieka w przeszłości i obecnie; obrona zasadniczych praw i swobód człowieka i dążenie do ich przestrzegania; kształtowanie doświadczenia historycznego w świadomości społecznej; rozwijanie społeczeństwa obywatelskiego w krajach o totalitarnej przeszłości i umacnianie zasad demokratycznego państwa prawa w tych krajach ${ }^{3}$.

${ }_{2}$ Zob. 20 лет обществу "Мемориал", portal Права человека в России, <http://www.hro. org/node/4370> [dostęp: 1 września 2016 roku].

3 Ibidem. 
Przypomnijmy, że „Memoriał” powstał jako masowy ruch spoleczny w końcu lat osiemdziesiatych XX wieku w zwiazku $\mathrm{z}$ wydarzeniami, które nastapily w wyniku reform wprowadzanych przez Michaiła Gorbaczowa po XXVII Zjeździe KPZR, odczytywanych jako zapowiedź dogłębnych zmian systemowych. Wówczas bowiem złagodzono państwowa cenzurę $\mathrm{w}$ mediach, co wywołało lawine publikacji o stalinowskim terrorze, skutkująca pewnym przebudzeniem społeczeństwa. Ludzie poczuli potrzebee odkrywania prawdy i wspólnego działania na różnych polach. Chociaż nie było pełnej wolności, pojawiła się szansa na przywrócenie społeczeństwu pamięci historycznej o reżimie komunistycznym, a historia powstania „Memoriału” pokazuje, ile wolno było w tamtych latach uzyskać i na jak wiele można było sobie pozwolić. Struktury państwowe i wielkie media pozostały poza tym ruchem społecznym, dysydenci natomiast wnieśli do niego swoje doświadczenie i wiedzę.

Ponieważ inicjatywa obywatelska przestała być uważana za przestępstwo, spontanicznie zaczęly pojawiać się pierwsze niezależne organizacje (kluby społeczne, stowarzyszenia młodzieżowe, zwiąki kulturalno-oświatowe itp.), które nazwano „nieformalnymi”. W Moskwie powstało kilka znaczacych klubów dyskusyjnych, w tym Klub Inicjatyw Społecznych i „Demokratyczna Pierestrojka”, które zrzeszały inteligentów oraz bardziej aktywnych działaczy społecznych i politycznych.

Kiedy prasa liberalna rozpoczęła kampanię na rzecz wypełniania „białych plam” historii, nieformalne grupy społeczno-polityczne podjęy temat destalinizacji. W sierpniu 1987 roku podczas pierwszej konferencji, dotyczącej roli inicjatywy obywatelskiej w pierestrojce, przedstawiciele „nieformalnych” wrócili do idei postawienia pomnika ofiar masowych represji politycznych w ZSRR. Był to pomysł, który zrodził się jeszcze w epoce Chruszczowa i nawet wpisano go do postanowień XXII zjazdu KPZR w 1961 roku, lecz później został odsunięty głęboko $\mathrm{w}$ niepamięć przez ugrupowanie Breżniewa, które w 1964 roku przejęło władzę. Tym razem pomnik miałby upamiętniać wszystkie ofiary represji, nie tylko te do- 
tychczas oficjalnie zrehabilitowane, a grupa wybranych obywateli zbierałaby fundusze i doglądała jego budowy. Spodziewano się, że władze pozytywnie odpowiedza na taka petycję ${ }^{4}$.

Nieco później idea budowy pomnika ofiar przekształciła się w szerszy projekt zbudowania kompleksu (memoriału) poświęconego pamięci historycznej - społecznego ośrodka badawczego, obejmującego ogólnodostępne muzeum, archiwum i bibliotekę, gdzie będa gromadzone i upowszechniane świadectwa epoki terroru. Promocja tego projektu stała się głównym zadaniem części osób z sekcji historyczno-oświatowej klubu „Demokratyczna Pierestrojka", które w październiku zjednoczyły się w nowo powstałej grupie "Memoriał"5.

Prawdopodobnie kilka miesięcy wcześniej grupa inicjatywna "Memoriału” zwróciłaby się $z$ odpowiednią petycja do Komitetu Centralnego i do rzadu. Niemniej przed jesienia 1987 roku zarysował się już pewien rozdźwięk pomiędzy polityka historyczna państwa a oczekiwaniami społecznymi. Najbardziej kontrowersyjnym aspektem projektu była szeroka definicja represji jako rozciagających się na czas przed tzw. kultem jednostki i po tym okresie. Memoriałowcy podjęli więc decyzję, żeby nie zwracać się bezpośrednio do władz, ale zapewnić sobie poparcie opinii publicznej, i dlatego zaczęli zbierać podpisy pod apelem wzywajacym do utworzenia „kompleksu poświęconego pamięci”. Moskiewska inicjatywa dosłownie w kilka dni została podchwycona przez obywateli w niektórych wielkich miastach, a w ciagu kolejnych miesięcy ruch memoriałowy objął niemal cały kraj. Akcja zbierania podpisów zjednoczyła ludzi i w wielu miejscach powstawały lokalne grupy „Memoriału”, zwłaszcza tam, gdzie znajdowały się największe stalinowskie obozy i miejsca kaźni. Podpisy były zbierane nie tylko na ulicach, w foyer teatrów czy w salach koncertowych.

\footnotetext{
4 K.E. Smith: Remembering Stalin`s Victims. Popular Memory and the End of the USRR, Cornell University Press, Ithaca, NY 1996.

$5 \mathrm{Na}$ początku była to grupa inicjatywna kilkunastu osób, do której należeli m.in.: Lew Ponomariew, Dmitrij Leonow, Nina Braginskaja, Paweł Kudiukin, Jurij Skubko, Wiktor Kuzin, Aleksiej Zwieriow, Aleksandr Wajsberg, Jelena Żemkowa, Oleg Orłow.
} 
Listy $z$ podpisami rozpowszechniano również starym sposobem - przekazywano je $z$ rak do rąk i kopiowano na bieżacco. Do wiosny 1988 roku pod petycja podpisało się około 50 tys. osób.

W tym czasie w grupie inicjatywnej „Memoriału”, w trakcie spotkań i nieraz burzliwych dyskusji między radykałami a działaczami o umiarkowanych poglądach dojrzewał projekt stworzenia masowej organizacji społecznej, która podejmowałaby różne działania na rzecz budowania pamięci historycznej, ponieważ obawiano się, że jeżeli władze same zajma się upamiętnianiem ofiar terroru, skończy się to na postawieniu pomnika „więźnia” w stylu socrealistycznym.

Tymczasem „Memoriał” zdobywał $z$ dnia na dzień nowych sprzymierzeńców. Zgłaszali się byli represjonowani lub ich krewni, przybywało zwolenników ruchu i wolontariuszy chętnych do współpracy (m.in. do zbierania ankiet $z$ danymi osób represjonowanych). Władze Moskwy wydały pozwolenie na dwa publiczne zgromadzenia (w maju i czerwcu), które przyciagnęły kilka setek uczestników i umożliwiły Andriejowi Sacharowowi oraz innym dysydentom, liberałom i młodym aktywistom wypowiedzenie się na temat wagi antystalinizmu i obywatelskich inicjatyw. To były pierwsze legalne wielkie mitingi w Moskwie ${ }^{6}$.

Na początku czerwca 1988 roku petycja „Memoriału” została przekazana Michaiłowi Gorbaczowowi, który na XIX konferencji KPZR osobiście sformułował propozycje dotyczace postawienia pomnika ofiar terroru. Nie wspomniał jednak ani o „Memoriale”, ani o muzeum, archiwum czy bibliotece. Ponieważ obawiano się, że projekt memoriałowców zostanie radykalnie zmieniony, postanowiono użyć wszelkich dostępnych środków, które pozwalałyby na przyciagnięcie uwagi: rozgłos w prasie, ważni protektorzy i publiczne współczucie dla represjonowanych. Na łamach „Litieraturnoj Gaziety" ukazało się ogłoszenie o zamiarze powołania Komitetu Społecznego „Memoriału”. W lipcu odbyły się niespotykane

6 О. Орлов, Т. Касаткина: Точность у нас "на кончиках пальиев", <http:/ /www.hro.org/ node/5762> [dostęp: 1 września 2016 roku]. 
dotąd wybory. Aktywiści „Memoriału” dosłownie wyszli na ulice i place dużych miast i przeprowadzili ankietę wśród przechodniów z pytaniem: „Kogo z działaczy społecznych, uczonych, pisarzy itp. chciał(a)byś widzieć w składzie takiego komitetu?”. Z zachowanych relacji wynika, że ludzie na ulicach odpowiadali $z$ chęcią, $z$ reguły nawet nie pytając, o co właściwie chodzi - jakby wszyscy wtedy wiedzieli, jakie cele ma „Memoriał”. Do Komitetu Społecznego, którego przewodniczącym został Andriej Sacharow, weszło wielu znanych ludzi. Wkrótce utworzono również Komitet Organizacyjny, którego zadaniem było przygotowanie planowanej na jesień konferencji założycielskiej Stowarzyszenia. Wkrótce jednak okazało się, że choć $z$ jednej strony „Memoriał” miał poparcie takich sponsorów instytucjonalnych, jak zwiąki artystów, filmowców, pracowników teatralnych, a także architektów i projektantów, pism „Ogoniok” i „Litieraturnaja Gazieta”, to z drugiej strony, pod naciskiem partyjnego Komitetu Centralnego słynne osobistości i zwiazki twórcze, które miały z założenia chronić organizację, próbowały przesunać termin konferencji. Tymczasem regionalne grupy „Memoriału” dążyły do pilnego zwołania zjazdu, który uprawomocniłby ich działania. Ostatecznie 29-30 października 1988 roku odbyła się konferencja, którą nazwano „przygotowawczą". Konferencja założycielska natomiast, w wyniku której oficjalnie utworzono Wszechzwiązkowe Dobrowolne Historyczno-Oświatowe Stowarzyszenie „Memoriał”, odbyła się w dniach 28-30 stycznia 1989 roku w Domu Kultury Moskiewskiego Instytutu Lotnictwa. Wzięło w niej udział kilkuset delegatów, reprezentujących około dwieście pięćdziesiąt regionalnych organizacji i ugrupowań $z$ ponad stu miast ${ }^{8}$.

\footnotetext{
$7 \mathrm{~W} 1992$ roku, po podpisaniu w grudniu 1991 roku układu białowieskiego o likwidacji ZSRR, wyrażenie "wszechzwiazkowe” w nazwie zastapiono przez "międzynarodowe”, a do określenia „historyczno-oświatowe” zostały dodane słowa „obrońców praw człowieka”.

8 Ministerstwo Sprawiedliwości ZSRR odmawiało zarejestrowania Stowarzyszenia aż do stycznia 1990 roku. Prawdopodobnie ostateczną decyzję o rejestracji podjał prezydent ZSRR. Na pogrzebie Andrieja Sacharowa w grudniu 1989 roku jego żona, Jelena Bonner, poprosiła o to Gorbaczowa.
} 
Od 1988 roku $\mathrm{z}$ inicjatywy społecznej zaczęto tworzyć archiwum, bibliotekę i muzeum „Memoriału”. Obecnie placówki te maja imponujące zbiory i odgrywają bardzo ważną rolę $\mathrm{w}$ działalności naukowo-historycznej i edukacyjnej Stowarzyszenia. Pracownicy i wolontariusze uczestniczą w różnych programach realizowanych przez moskiewskie i regionalne organizacje „Memoriału”. Przygotowuja wystawy, które sa prezentowane nie tylko w Moskwie, seminaria, wykłady, lekcje historii dla młodzieży, studentów i nauczycieli, a także spotkania tematyczne, na przykład $z$ byłymi represjonowanymi. W zbiorach archiwum przechowuje się m.in. ankiety represjonowanych, kopie dokumentów archiwalnych, pozyskane w toku realizacji poszczególnych programów. Oddzielne miejsce zajmuja zbiory "historii mówionej” - nagrane i spisane relacje świadków. Muzeum „Twórczość i życie Gułagu” powstało dzięki osobom prywatnym, które podarowały różne przedmioty wytworzone w miejscach uwięzienia, rysunki, fotografie itp. Część eksponatów „Memoriał” przywiózł $z$ dawnych obozów, kopie fotografii udało się pozyskać $z$ archiwów państwowych. Muzeum formalnie zostało otwarte w 1990 roku, ale już wcześniej, przy okazji wystaw i spotkań publicznych, które organizował „Memoriał”, darczyńcy przynosili cenne pamiątki. Trudno opisać, ile pracy wymaga tworzenie zaplecza dokumentacyjnego, dotyczacego tak wielkich obszarów przeszłości, które systemowo były zakłamywane przez władze komunistyczne.

I choć pomnika ofiar represji politycznych w Moskwie dotychczas nie postawiono, to jednak 30 października 1990 roku z inicjatywy „Memoriału” i przy jego aktywnym udziale naprzeciwko Łubianki ustawiono potężny głaz przywieziony z Sołówek. Od tego czasu przy Kamieniu Sołowieckim corocznie 29 października spotykają się mieszkańcy Moskwy, żeby wziąć udział w symbolicznym „przywracaniu imion” ofiarom terroru.

Najefektywniejsze działania „Memoriału”, mające na celu upamiętnianie ofiar terroru państwowego przez ustalanie i publikowanie imiennych spisów osób represjonowanych, ujawnianie miejsc 
ich rozstrzeliwań i pochówku oraz stawianie na tych miejscach pamiątkowych znaków, przypadaja na lata 1991-1999, kiedy dostęp do archiwów był niemal nieograniczony, a badaniami historycznymi interesowało się wiele osób, w tym pracowników instytucji państwowych.

$\mathrm{Na}$ przełomie lat osiemdziesiątych i dziewięćdziesiątych $\mathrm{XX}$ wieku „Memoriał” zainicjował niżej opisane programy historyczne. Jednocześnie od początku oficjalnej działalności uczestniczy $\mathrm{w}$ przygotowaniu ksiąg pamięci, w których umieszczane sa krótkie noty biograficzne ofiar represji, opracowane na podstawie dokumentacji zachowanej $\mathrm{w}$ resortowych archiwach posowieckich. Księgi te zostały opublikowane w różnych regionach Rosji przy współpracy archiwów państwowych, muzeów, bibliotek, organizacji społecznych itp. W opracowywaniu ksiag biora aktywny udział również regionalne oddziały „Memoriału”, m.in. w Republice Komi, Kraju Krasnojarskim, Krasnodarskim, Chabarowskim, w obwodach nowosybirskim, orenburskim, astrachańskim i innych. Zbieraniem danych ofiar represji zajmuja się także organizacje związane $z$ „Memoriałem” działające na Białorusi, Ukrainie, Łotwie czy w Kazachstanie. Od 1998 roku informacje $z$ ksiag pamięci zaczęto wprowadzać do zbiorczej bazy danych Ofiary Terroru Politycznego w ZSRR ${ }^{9}$, udostępnionej następnie na stronach internetowych „Memoriału”, a także wydanej na płycie CD. Do bazy wprowadzane sa również dane pozyskane dzięki kwerendom archiwalnym programu „Losy więźniów politycznych w latach komunistycznego terroru" ${ }^{10}$.

W trakcie pracy memoriałowców nad księgami pamięci sukcesywnie sa ustalane i udostępniane na portalu Wirtualne Muzeum Gułagu informacje o miejscach pochówku ofiar terroru i pamiątkowych znakach, które im poświęcono. Koordynatorem tego pro-

\footnotetext{
9 Жертвы политического террора в СССР, <http://lists.memo.ru/index1.htm> [dostęp: 1 września 2016 roku].

${ }^{10}$ Судьбы политзаключенных в годы коммунистического террора, <http://www.memo. $\mathrm{ru} / \mathrm{d} / 3341 . \mathrm{html}>$ [dostęp: 1 września 2016 roku].
} 
jektu jest Naukowo-Informacyjne Centrum „Memoriału” w Sankt Petersburgu ${ }^{11}$.

Kolejnym Memoriałowym projektem jest „Topografia terroru” ${ }^{2}$. Celem programu, istniejacego od 2008 roku, jest ustalanie informacji o zachowanych na terenie Rosji obiektach zwiazanych $z$ historia represji, takich jak np. gmachy organów NKWD, więzienia, tereny obozów i kolonii poprawczych, osad specjalnych, miejsca straceń i nekropolie. Jednym $z$ efektów projektu są krótkie przewodniki, wydawane siłami regionalnych organizacji „Memoriału", przeznaczone dla nauczycieli, krajoznawców itd. W 2011 roku ukazało się sześć takich publikacji (w formie przewodników po mieście), w których przedstawiono historię represji politycznych w Woroneżu, Komsomolsku nad Amurem, Krasnojarsku, Penzie, Riazaniu oraz w Syktywkarze w Republice Komi.

Do „Topografii terroru” zbliżony jest program „Ślady terroru” tworzony na portalu Wirtualne Muzeum Gułagu. Dotychczas zgromadzono w nim informacje o ponad stu pięćdziesięciu obiektach na terenie całego kraju. W Moskwie program ten ma nazwę „Moskwa: miejsca pamięci” i jest ściśle związany z październikowa akcja „Przywracanie imion” przy Kamieniu Sołowieckim, która polega na wielogodzinnym odczytywaniu krótkich biogramów (imię, nazwisko, wiek, zawód i data egzekucji), przygotowanych wcześniej na podstawie memoriałowej bazy danych, i zapalaniu zniczy. Jednocześnie na placu przed Łubianka organizowane sa wystawy tematyczne i wycieczki po obiektach zwiazanych $z$ represjami na terenie Moskwy. Obecnie w „Memoriale” trwaja prace nad mapa represji i internetowym indeksem miejsc zamieszkania rozstrzelanych mieszkańców stolicy. Wydano pierwszy zestaw kart pocztowych przedstawiających domy, w których w latach terroru aresztowano wielu mieszkańców. Należy zaznaczyć, że akcja „Przywracanie imion” jest organizowana przez międzynarodowy „Me-

\footnotetext{
${ }_{11}^{11}$ Виртуальный музей ГУААГа, <http://www.memo.ru/d/3332.html> [dostęp: 1 września 2016 roku].

${ }_{12}$ Tonozpaфuя meppopa, <http://www.memo.ru/d/3352.html> [dostęp: 1 września 2016 roku].
} 
moriał" w wielu miastach i z każdym rokiem uczestniczy w niej coraz więcej osób.

Wśród programów historycznych, koordynowanych przez Ośrodek Badań, Informacji i Upowszechniania „Memoriał” szczególną uwage zwraca „Program polski” prowadzony przez Komisję Polską ${ }^{13}$. Dokumentowanie losów obywateli II Rzeczpospolitej nie oznacza, że „Memoriał” wyznaje zasadę badania sowieckich represji politycznych według klucza narodowości lub obywatelstwa osób represjonowanych. Dla „Memoriału” losy Polaków są częścią historii sowieckiego reżimu, a sprawa zbrodni katyńskiej jest „jednym $z$ elementów nieukończonego procesu rozliczania stalinizmu w Rosji"14.

W latach 1993-1995 pod kierunkiem Aleksandra Gurjanowa, przewodniczącego Komisji Polskiej, został zrealizowany program badań archiwalnych, którego efektem jest wydany przez „Memoriał” w 1997 roku zbiór artykułów Represje przeciw Polakom $i$ obywatelom polskim ${ }^{15}$. Na podstawie ówczesnych badań przeprowadzonych w centralnych archiwach Rosji (m.in. w Archiwum Prezydenta Federacji Rosyjskiej, Archiwum Państwowym FR, Rosyjskim Państwowym Archiwum Wojskowym) moskiewscy historycy oszacowali łączna liczbę Polaków i obywateli polskich poddanych w latach 1939-1956 wszystkim rodzajom represji politycznych na około 530-580 tys. osób. W tym ustalono, że w latach 1940-1941 deportowano w głąb ZSRR około 320 tys. osób, co było przełomem w dotychczasowej historiografii polskiej, w której pisano o niemal dwóch milionach wywiezionych ${ }^{16}$. Od 1996 roku w ramach „Programu polskiego” zaczęto tworzyć kompute-

\footnotetext{
${ }^{13}$ Komisja Polska została utworzona na poczatku lat 90. XX wieku przez Annę Griszyną. Zob. m.in.: T. Pieńkowski: Sympozjum katyńskie w Moskwie. „Wojskowy Przegląd Historyczny" 1989, nr 1-2, s. 264-267; R. Januszewski, J. Strękowski: Polska w oczach cudzych, Towarzystwo Przyjaciół Ossolineum, Wrocław 2003, s. 227-267.

${ }^{14}$ Zob. Aleksander Gurjanow: Udowodnić Katyń, rozm. przepr. T. Kizny, „Newsweek Historia" 2016, nr 7, s. 41.

${ }_{15}$ А. Гурьянов (red.): Репрессии против поляков и польских граждан, Звенья, Москва 1997 <http://www.memo.ru/history/POLAcy/Index.htm> [dostęp: 1 września 2016 roku].

${ }^{16}$ A. Gurjanow: Cztery deportacje 1940-41, „Karta” 1994, nr 12, s. 114-136.
} 
rowe zestawienia imienne (bazy danych), obejmujace całościowe grupy represjonowanych. Było to możliwe przy ówczesnym dostępie do archiwaliów sowieckich i dzięki zaangażowaniu archiwistów z Centrum Przechowywania Zbiorów Historyczno-Dokumentalnych w Moskwie, a także pracowników archiwów resortowych Urzędów Spraw Wewnętrznych w Archangielsku, Workucie, Wołogdzie, Permie oraz działaczy miejscowych „Memoriałów” (m.in. w Riazaniu, Syktywkarze i w Workucie).

Prace prowadzono $\mathrm{w}$ ścisłej współpracy $z$ warszawskim Ośrodkiem KARTA, gdzie przygotowane przez „Memoriał” na podstawie archiwalnych źródeł NKWD i uzupełnione o źródła polskie zestawienia (zawierajacce w sumie 119905 biogramów, czyli około 21-23 proc. ogółu obywateli polskich represjonowanych przez władze ZSRR $z$ powodów politycznych) zostały opublikowane w serii wydawniczej „Indeks Represjonowanych”, a następnie udostępnione w zbiorczej bazie danych „Memoriału” - Ofiary Terroru Politycznego w ZSRR.

„Program polski” w latach dziewięćdziesiątych XX wieku nie objął badaniami zbrodni katyńskiej, między innymi dlatego, że wówczas tym tematem zajmowali się naukowcy i prokuratorzy wojskowi w ramach oficjalnego śledztwa. Od 2005 roku, po umorzeniu przez Główna Prokuraturę Wojskową rosyjskiego śledztwa, „Memoriał” rozpoczą batalię sądowa na rzecz imiennej rehabilitacji ofiar oraz ostatecznego wyjaśnienia i rozliczenia zbrodni katyńskiej. Wszystkie kroki podjęte $\mathrm{w}$ tym celu zakończyły się niepowodzeniem. Prokuratura odmowę imiennej rehabilitacji uzasadnia brakiem dokumentów potwierdzających zabójstwo każdego jeńca $z$ osobna. W związu $z$ tym Komisja Polska we współpracy $z$ Ośrodkiem KARTA opracowała nowe zestawienie imienne ofiar zbrodni katyńskiej - księge pamięci Ubity w Katyni ${ }^{17}$, która „Memoriał” wydrukował dzięki środkom Rosjan, zgromadzonym w wyniku internetowej

\footnotetext{
${ }_{17}$ А. Гурьянов, А. Дзенкевич, А. Рачинский: Убиты в Катыни, Звенья, Москва 2015. W 2013 roku Ośrodek KARTA opublikował zestawienie Zabici w Katyniu jako XXI tom serii „Indeks Represjonowanych”. Wydanie rosyjskie księgi pamięci z 2015 roku zostało znacznie rozszerzone i uzupełnione.
} 
zbiórki. W każdym z 4415 biogramów opublikowanych w księdze umieszczono odniesienia do źródeł dokumentalnych, które spełniają wymogi postępowania dowodowego.

Według Aleksandra Gurjanowa, koordynatora „Programu polskiego”, sprawa zbrodni katyńskiej, będąc tematem badań historycznych, jednocześnie jest w Rosji aktualnym problemem prawnym i edukacyjnym - „Memoriał” zmuszony jest do udowadniania rzeczy oczywistych $z$ jednej strony $w$ sporach $z$ prokuratura i sadami, a $z$ drugiej $-z$ orędownikami negacji sowieckiej odpowiedzialności za zbrodnię.

Odpowiadając na pytanie, czego jeszcze brakuje do wyjaśnienia i rozliczenia zbrodni katyńskiej, Gurjanow na pierwszym miejscu wymienia potrzebę przekonania szerokiej opinii publicznej w Rosji, że zbrodni dokonało NKWD, ponieważ:

[...] negacjonizm Katynia jest podsycany przez radykalne, hałaśliwe środowiska, które nazwałbym sojuszem stalinowców $\mathrm{z}$ "prawdziwymi patriotami». To ludzie ogarnięci nostalgia za imperium i utraconym mocarstwowym statusem Rosji. Taka postawa współgra $z$ historyczna polityka państwa, polegająca na podkreślaniu chlubnych kart historii, przede wszystkim zwycięstwa nad faszyzmem, a przemilczaniu lub umniejszaniu rzeczy haniebnych $[\ldots]^{18}$.

Zdaniem Gurjanowa, niemniej ważna jest właściwa kwalifikacja prawna zbrodni, a także: wskazanie w trybie procesowym nazwisk wszystkich zbrodniarzy ${ }^{19}$, którzy powinni być prawnie uznani za sprawców, odtajnienie i udostępnienie badaczom oraz opinii publicznej wszystkich dokumentów, dotyczących zbrodni katyńskiej i przede wszystkim imienna rehabilitacja każdego rozstrzelanego jeńca i więźnia ${ }^{20}$.

\footnotetext{
${ }^{18}$ Zob. A. Gurjanow: Udowodnić Katyń, s. 38.

${ }^{19} \mathrm{~W}$ listopadzie 2015 roku Centrum Polsko-Rosyjskiego Dialogu i Porozumienia opublikowało niezwykle cenna ksiażkę Poczet katów katyńskich, autorstwa znakomitego historyka, współzałożyciela „Memoriału”, Nikity Pietrowa. Jak zauważył Pietrow, odnalezieni przez niego, nieliczni co prawda, krewni zbrodniarzy bronią swoich przodków, nie przyjmując do wiadomości faktów.

${ }^{20}$ A. Gurjanow: Zbrodnia Katyńska. Problemy nie tylko badawcze widziane z Moskwy, referat wygłoszony 19 kwietnia 2016 na XVIII Dorocznej Sesji Katyńskiej: Zbrodnia Katyńska.
} 
Jak wynika $z$ dotychczasowych doświadczeń, niedemokratyczna Rosja nie jest zainteresowana imiennym dokumentowaniem represji politycznych. Ofiary reżimu maja pozostać anonimowe. Tymczasem, według „Memoriału”, liczby wzbudzaja tylko współczucie, które nie ma nic wspólnego $z$ prawdziwym zrozumieniem, na czym polega terror państwowy. Opisywanie przeszłości przez pryzmat losów pojedynczych ludzi, a także rodzin, małych grup, ale przede wszystkim osób i wykorzystywanie w tym celu wspomnień, relacji, dokumentów osobistych, fotografii itp., jest bardzo istotnym novum w uprawianiu i prezentacji historii. Niestety, mozolne gromadzenie danych zainicjowane przez ruch społeczny w końcu lat 80. XX wieku nie ma wsparcia instytucjonalnego.

„Memoriał” gromadzi fakty, buduje wiedzę, ale, jak się okazuje, nie zawsze prowadzi to do jej zrozumienia. Pomimo wieloletnich starań niezmiernie trudne okazuje się uświadomienie społeczeństwu rosyjskiemu podstawowej zasady, że państwo jest dla człowieka, a nie człowiek dla państwa.

$O$ ile na początku pieriestrojki Stalin, zgodnie $z$ sondażami, nie pojawiał się nawet w pierwszej dziesiątce najbardziej wpływowych ludzi w Rosji, o tyle mniej więcej od 2012 roku zajmuje pierwsze pozycje i obecnie jego popularność nadal rośnie. Miliony Rosjan wiedza, że ich przodkowie sa niewinnymi ofiarami terroru, że zostali zabici nie wiadomo za co i nie wiadomo gdzie, a jednocześnie rośnie liczba stalinistów, którzy uważaja, że Stalin dał krajowi więcej dobra niż zła.

Zdaniem Arsienija Roginskiego, przewodniczącego zarządu Międzynarodowego Stowarzyszenia „Memoriał”, przekonanie, że stalinowski terror był terrorem państwa wymierzonym przeciwko człowiekowi, $z$ trudem przebija się do masowej świadomości. Jednym $z$ rezultatów polityki historycznej prowadzonej przez państwo jest brak w społeczeństwie całościowego obrazu terroru $-z$ jego przyczynami i następstwami, sa tylko oddzielne fakty. W polity-

Polska a Rosja. Wyjście z Kryzysu Prawdy; zob. także A. Gurjanow: "Memoriał" a Katyń, w: A. Dzienkiewicz (red.): Rosja a Katyń, Ośrodek KARTA, Warszawa 2010, s. 113-141. 
ce tej wszystko, co jest związane $z$ terrorem, zostało odsunięte na możliwie najdalszy plan, a pozostała tylko chwalebna przeszłość. Jak mówi Roginski:

[...] nas wszystkich łączy to, że czcimy pamięć ofiar. Dzieli zaś to, że jedni szukaja przyczyn terroru, a inni te poszukiwania traktuja jak oczernianie historii. [...] Do dzisiaj nie powstał żaden akt prawny, który mówiłby, że za śmierć tych ofiar odpowiada państwo. A od tego należałoby zacząć - od osązenia państwa jako sprawcy terroru ${ }^{21}$.

Tymczasem, wobec zbliżających się w 2017 roku okrągłych rocznic wydarzeń $z$ lat 1917 i 1937, prezydent Władimir Putin jesienia 2014 roku osobiście podją decyzję o budowie pomnika ofiar represji w Moskwie, a w sierpniu 2015 roku została zatwierdzona przez premiera Dmitrija Miedwiediewa oficjalna Koncepcja państwowej polityki upamiętniania ofiar represji politycznych, która ma być realizowana do końca 2019 roku. Przedstawiono w niej w sposób bardzo ogólny „zadania na rzecz upamiętniania ofiar, które maja się przyczynić do rozwoju współpracy partnerskiej między państwem a społeczeństwem obywatelskim, mają wzmocnić międzypokoleniowe relacje, zapewnić ciagłość doświadczenia kulturowego i służyć patriotycznej edukacji młodzieży"22.

Po ogłoszeniu decyzji Putina o budowie pomnika ofiar totalitaryzmu i rozpisaniu konkursu na jego projekt w siedzibie głównej „Memoriału” w dniu 16 marca 2015 roku odbyła się dyskusja, podczas której m.in. pytano: Jak możliwe jest stawianie pomnika ofiarom represji politycznych, jeżeli prześladowania trwaja nadal? Czy będzie to pomnik ofiar czy też monument świadczacy o okrucieństwie tego państwa? ${ }^{23}$.

\footnotetext{
${ }^{21}$ А. Рогинский: Память о сталинизме, <http://www.memo.ru/d/518.html> [dostęp: 1 września 2016 roku]; zob. A. Roginski i Je. Żemkowa: Archipelag wolności, rozm. przepr. T. Kizny, „Newsweek Historia” 2016, nr 6, s. 31.

22 Об утверждении кониепиии государственной политики по увековечению памяти жертв политических репрессий, <http://government.ru/docs/19296/> [dostęp: 1 września 2016 roku].

${ }_{23}^{23}$ Дискуссия о памятнике жертвам политических репрессий, <http://www.memo.ru/ -d/229244.html> [dostęp: 1 września 2016 roku]; zob. też: Точка исторической памяти, <http://lenta.ru/articles/2015/10/01/gulag/> [dostęp: 1 września 2016 roku].
} 
Dyskusję podsumował Arsienij Roginski, który wyjaśnił, jaka treść nadawał pomnikowi „Memoriał”, gdy w 2010 roku zwracał się $\mathrm{w}$ tej sprawie do prezydenta Miedwiediewa:

[...] Wychodziliśmy z założenia, że jest Kamień Sołowiecki i że to jest nasz pomnik, my go postawiliśmy. I zawsze mówiliśmy, że w Rosji nie ma pomnika postawionego w imieniu państwa. Do czego jest to nam potrzebne? Tylko do tego, aby państwo chociaż raz w życiu wyraźnie powiedziało: terror jest złem. Więcej od państwa niczego nie chcemy. Nie interesuje mnie, czy państwo powie to szczerze czy obłudnie. [...] Ważne, żeby państwo to powiedziało. Wtedy nauczycielka Maria Iwanowna, dla której teraz jest to temat na wpół legalny (nauczyciele i bibliotekarze, którzy jeszcze pięć lat temu organizowali wieczory tematyczne poświęcone terrorowi, teraz już boją się to robić), będzie mogła powiedzieć: zobaczcie - państwo postawiło pomnik, więc to znaczy... Nieważne, co powie Maria Iwanowna do lokalnego przedstawiciela władzy, ważne, że dla niej będzie to jakiś argument. Tak samo będzie mówić każda nauczycielka w Moskwie, która przyprowadzi pod ten pomnik swoich uczniów i będzie musiała coś powiedzieć. I wreszcie będzie to swego rodzaju opowieść o tym, że rozprawianie się z ludźmi bez sądu, do czego dochodziło, jest bardzo złe. I to już samo w sobie będzie sukcesem ${ }^{24}$.

Przypomnijmy, że „Memoriał” w czasie prezydentury Dmitrija Miedwiediewa dwukrotnie zwrócił się do prezydenta $z$ prośba o utworzenie państwowego memorialno-muzealnego kompleksu poświęconego pamięci ofiar stalinowskich represji, przedstawiając jednocześnie jego szczegółowy projekt. Pod pismem-apelem „Memoriału", podpisali się przedstawiciele organizacji społecznych, eksperci $z$ instytucji naukowych, historycznych i archiwalnych, przedstawiciele regionalnych organizacji „Memoriału”, dziesiątki małych muzeów prowincjonalnych, które zachowuja pamięć o ofiarach stalinizmu, a także biznesmeni, ofiarowując merytoryczna pomoc i wsparcie finansowe. Reakcja ówczesnego prezydenta Miedwiediewa (a także premiera Putina) była przychylna, ale nie podjęto żadnych działań. Obie decyzje - dotyczaca budowy pomnika ofiar oraz zatwierdzenie koncepcji polityki państwa w sprawie upamiętniania

\footnotetext{
${ }^{24}$ Ibidem.
} 
ofiar - wywołuja mieszane uczucia, ponieważ trudno jest powiedzieć, jakie sa cele władzy, i przewidzieć, jak będzie wyglądała ich realizacja. Czas pokaże, czy dojdzie do rozliczenia totalitarnej przeszłości sowieckiej, czy skończy się na tylko symbolicznych działaniach, które maja poprawić wizerunek władzy.

Według opinii „Memoriału”25 opublikowana 18 sierpnia 2015 roku na rządowej stronie internetowej Koncepcja państwowej polityki upamiętniania ofiar represji politycznych, zatwierdzona przez premiera Miedwiediewa, pomimo różnych krytycznych uwag i zastrzeżeń, jest ważnym dokumentem. Przede wszystkim dlatego, że pierwszy raz od ustawy $O$ rehabilitacji ofiar represji politycznych, uchwalonej 18 października 1991 roku przez Radę Najwyższą Federacji Rosyjskiej, w oficjalnym państwowym dokumencie umocowano stosunek państwa do sowieckiego terroru politycznego. I jeśli wierzyć temu, co zostało zapisane w tekście dokumentu, jest to stosunek negatywny ( $\mathrm{w}$ domyśle - potępiajacy terror polityczny).

Dokument ten ma znaczenie również dlatego, że chociaż nie jest rozporządzeniem adresowanym do konkretnego odbiorcy, może być, i z cała pewnościa będzie wykorzystywany przez tych, którzy są szczerze oddani sprawie utrwalania pamięci o terrorze politycznym. Powołując się na Koncepcje polityki państwa..., w której między innymi napisano, że „Rosja nie może być w pełni praworządnym państwem i odgrywać znaczącej roli w społeczności międzynarodowej, nie utrwalając pamięci o milionach swoich obywateli będących ofiarami represji politycznych"26, będą oni mogli domagać się od miejscowej władzy wsparcia w poszukiwaniu miejsc pochówku ofiar represji, w przygotowaniu i publikacji ksiąg pamięci, ustawianiu pamiątkowych tablic i innych znaków pamięci.

\footnotetext{
${ }^{25}$ Ауч света из ГУ ААГа, „Nowaja Gazieta” 2015, nr 92, <http://www.novayagazeta.ru/ society/69685.html> [dostęp: 1 września 2016 roku].

${ }^{26}$ Zob. Кониепиия государственной политики по увековечению памяти жертв политических репрессий,

<http://government.ru/media/files/AR59E5d7yB9LddoPH2RSlhQpSCQDERdP.pdf> [dostęp: 1 września 2016 roku].
} 
Można też mieć nadzieję, że chociaż w niewielkim stopniu w przyszłości dokument ten stanie się przeszkoda $\mathrm{w}$ procesie powrotu symboli sowieckich i stereotypów, że utrudni tzw. prawdziwym patriotom stawianie pomników Stalinowi, Dzierżyńskiemu itp.

Tak więc, zdaniem „Memoriału”, dobrze, że pojawiła się koncepcja, która może stać się narzędziem w rękach społeczeństwa, chociaż w zasadzie nie pasuje ona do dzisiejszej polityki historycznej Rosji, w której nie ma miejsca dla obiektywnego przedstawiania $\mathrm{i}$ interpretowania faktów ${ }^{27}$. Na przykład w rekomendowanych przez państwo podręcznikach do historii temat stalinizmu jest obecny jako zjawisko systemowe, co według Arsienija Roginskiego, mogłoby się wydawać sukcesem. Ale, jak podkreśla przewodniczacy "Memoriału”, „terror w tym ujęciu ma charakter uzasadnionego narzędzia realizacji celów państwa tak jakby nie było innej alternatywy. Taka koncepcja nie wyklucza okazywania współczucia ofiarom "molocha historii", ale kategorycznie nie dopuszcza stawiania pytań o sprawcę tej zbrodni"28. Zgodnie $z$ polityka historyczna państwa należy kształtować poczucie dumy ze swojego kraju. W tym kontekście wydaje się, że jednym $z$ głównych celów podjętej w końcu 2012 roku ustawy o „organizacjach pełniących funkcje agentów zagranicznych" jest kompromitowanie ludzi i środowisk podejmujacych próby obiektywnego przedstawiania historii. O braku tolerancji władzy dla niezależnego myślenia świadczy również wprowadzanie kolejnych ustaw ograniczajacych taka aktywność społeczną, która podaje w wątpliwość prawomocność państwa (m.in. ustawa zaostrzajacca kary za udział w demonstracjach ulicznych i jakichkolwiek akcjach publicznych).

Dwadzieścia lat temu, w maju 1996 roku Siergiej Kowalow, przewodniczacy zarząu Rosyjskiego Stowarzyszenia „Memoriał” powiedział, że „po władzy w Rosji niczego dobrego spodziewać się nie należy. Jeśli można na coś liczyć, to tylko na oddolny ruch

\footnotetext{
${ }^{27}$ Ауч света из ГУ АГГа, „Nowaja Gazieta” 2015, nr 92, <http://www.novayagazeta.ru/ society/69685.html>; J. Raczynski: "Memoriał” a bezprawie, „Karta” 2016, nr 88, s. 134-137. ${ }^{28}$ Zob. A. Roginski i Je. Żemkowa: Archipelag wolności, s. 31.
} 
społeczny tworzący ośrodki stymulujące powstawanie społeczeństwa obywatelskiego"29.

Powszechnie ocenia się obecny stan społeczeństwa obywatelskiego w Rosji jako krytyczny. Tymczasem Grigorij Ochotin, który jest członkiem zarządu międzynarodowego „Memoriału”, w artykule Wolność oddolna. Rozwój społeczeństwa obywatelskiego $w$ Rosji stwierdza $z$ optymizmem, że „ostatnie trzydzieści lat należy traktować raczej jako proces ciagłego rozwoju i umacniania się rosyjskiego społeczeństwa obywatelskiego [...] i że atak państwa na $\mathrm{NKO}^{30}$ oraz aktywistów obywatelskich świadczy o ich sile. W ciagu trzydziestu lat społeczeństwo obywatelskie stało się na tyle silne i zorganizowane, żeby stanowić jeśli nawet nie realne, to przynajmniej urojone zagrożenie dla niedemokratycznego reżimu"31.

\footnotetext{
${ }^{29}$ Misja Kowaliowa. Rzecz o Siergieju Adamowiczu Kowaliowie i jego współpracownikach, którzy $w$ krytycznym dla Rosji momencie znaleźli się $w$ Czeczenii, oprac. P. Mitzner, Ośrodek KARTA, Warszawa 1996, s. 144.

${ }^{30} \mathrm{NKO}$ - organizacje niekomercyjne w Rosji (HKO - некоммерческая организация). O роgorszeniu sytuacji organizacji pozarzadowych w Rosji od listopada 2012 roku, wraz z wejściem w życie tzw. ustawy o zagranicznych agentach zob. artykuł $W$ obronie sumienia, oprac. A Richter: „Karta” 2015, nr 83, s. 144-147.

${ }^{31}$ Г. Охотин: Свобода снизу: развитие гражданского общества в России, <http://last30. $\mathrm{ru} /$ issue/civil-society/opinion/> [dostęp: 1 września 2016 roku].
} 